\title{
Shared Visions, Shared Wildernesses: Wilderness Conservation in the Grasslands of Southern Saskatchewan*
}

Two centuries of hunting, agriculture and economic development have caused declining biodiversity and ecological integrity in the prairie ecozone of southern Saskatchewan. The environmental revolution that started in the 1970s brought a renewed vision to protect remaining wildlife and its habitat, and restore keystone mammals. NGOs and government agencies are acting as partners in this vision, and have been increasingly successful in working cooperatively with land-users such as ranchers, farmers and the water and energy industries. New conservation areas and new initiatives to reintroduce extirpated animals and their habitat offer hope to those who wish to see a new balance between prairie inhabitants and wild nature. However, conservation is not an exact science, and 'fashions' and 'agendas' exist, with inevitable debates about priorities. The article assesses the successes and limitations of these conservation initiatives in the Saskatchewan prairies, and draws conclusions relevant to nature conservation in Canada as a whole.

\section{Concepts of Wilderness and Conservation}

To enter the wilderness is to go backwards in time, which may account for the relentless elegiac and archaeological streak in Canadian literature. Margaret Atwood, Strange Things (1995: 49)

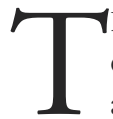

HE APPRECIATION AND ENJOYMENT OF WILDERNESS is a distinctive part of Canadian life and culture. Concern for wilderness, and its three strands of natural environment, parks and recreation, consistently ranks alongside global peace-keeping, multiculturalism, sport and social tolerance as a key pillar in the fabric of Canadian society according to polls of citizens and visitors alike (Environment Canada 1999). Nations are frequently judged by the way they treat their land, water, flora and fauna. A popular indicator of these environmental credentials among

* Colour versions of Figures 3 and 4 in this article are included in this online version only. 
bureaucrats, the general public, the media, corporate institutions and politicians is the ecological index of biodiversity. This concept is widely used because it is relatively easily understood. However, most ecologists and conservation scientists prefer to use the index of ecological integrity, a term prominent in ecological writings and in government documents such as state of the environment reports and national park management plans. This indicator measures how healthy the ecological components of a specific ecosystem are, and how well they are working together.

Wild areas are areas where ecological, physical-geographical and geological processes reign supreme. I have previously explored the debate over defining wilderness areas and what is 'natural' in my British Association for Canadian Studies Presidential Address of 2002 (Atkinson 2003). There it was noted that the USA was the first country to give a legal definition of wilderness in its Wilderness Act of 1964: 'an area where the earth and its community are untrammelled by man, where man himself is a visitor who does not remain' (US Wilderness Act, 1964, Section 2). However, the requirement for non-human landscapes in this definition ignores the long-range transport of pollutants that is characteristic of today's earth. It is also unrealistic because it omits aboriginal peoples who, since prehistoric times, have used all the wildernesses on earth (apart from Antarctica) for hunting and herding animals, and for food gathering. In Canada, where there is respect for past and present aboriginal peoples, a more appropriate definition of wilderness is the one suggested by Harold Eidsvik, a former Director of Strategic Planning in Parks Canada: 'wilderness is an area where natural processes dominate, yet where people also coexist, as long as their technology and impacts do not endure' (Eidsvik 1989: 80).

Wilderness is inevitably viewed through national 'cultural spectacles'. In the UK, where there are few areas to match the imposing wildernesses of North America, government agencies and NGOs managing wilderness and advising governments on nature conservation define wilderness in the context of its past and present utility. Scottish Natural Heritage $(\mathrm{SNH})$, the chief government adviser on wildlife, landscape and national parks in Scotland, avoids using the term 'wilderness' altogether, preferring 'wildland' instead, and defining it as: 'relatively remote and inaccessible land, not noticeably affected by contemporary human activity, and offering high-quality opportunities to escape from the pressures of everyday living and to find physical and spiritual refreshment' (SNH 2002: 5). The reference to 'physical and spiritual refreshment' points to the longstanding paradox in wilderness management. On the one hand, the 
ecological imperative judges these landscapes and their natural flora and fauna to be priceless and beyond value, to be preserved in their own right, whatever the cost. Wilderness should never be brought under human domination, as illustrated by the words of Stan Rowe, one of Canada's most famous late-twentieth-century conservationists: 'Wildness is the unpossessed, and the lesson all humanity needs to learn is that possession of nature, working our will on every part of the world, is the road to environmental destruction and the ruination of the race' (Rowe 1992: 994). On the other hand, Canadians and tourists enjoy visiting these wildernesses for recreation and leisure, and maintaining the ecological integrity of landscapes and ecosystems in the face of pressures from such visits is the major challenge for conservationists and recreation managers alike.

\section{Geographical Background to the Prairies}

It is a story of the tragedy of the disappearance of the commons on the prairies after 1870 .

Irene Spry (1976: 21)

The 'prairie ecozone' occupies one-sixth of the continental area of Canada, the USA and Mexico, but only 5 per cent of Canada's geographical area. However, its importance to the country in terms of economy, history and settlement, together with its iconic status in the arts, far exceeds this small proportion. Its position mid-continent and in the rain-shadow of the Rockies makes it the driest part of Canada, apart from the Arctic; it has a variable, and therefore unpredictable, mean annual precipitation of less than 300 millimetres. That part of the prairie ecozone which lies in the southern part of Saskatchewan comprises four ecoregions: aspen parkland, moist mixed grassland, mixed prairie grassland and Cypress upland. Mixed prairie grassland (or mixed prairie) is the focus of this article. The southern section of the mixed prairie grassland is known to geographers as Palliser's Triangle, after Captain John Palliser's 1857-60 British North America expedition. Palliser's judgement that the region was unfit for arable agriculture and would only support extensive ranching is thought to have been influenced by the drought conditions during the expedition. Henry Hind's expedition of 1858 reached a similar conclusion, but John Macoun, who visited in the wetter years of 1875 and 1879, disagreed and was convinced that arable agriculture was viable down to the 49th parallel. 
Two factors have determined the prosperity of prairie farming over the past 130 years. First, periodic droughts - like those of the early 1920 s, 1930s and late 1980s - bring poor harvests and low economic returns, only partially relieved by federal government subsidies. Other climatic events, like hail and early autumn frosts, can be devastating too. The second influence on prairie farming prosperity is the buoyancy of international grain markets. Current high grain prices not only increase foreign exchange earnings and farm incomes, but also signal more conversion of range and unused land to crop farming. In short, economic prosperity increases the effort and determination needed for the meaningful conservation of ecosystems and wildlife. In times of buoyant economic conditions, prairie farmers and ranchers are less ready to accept the modest (compared to market prices for food) financial incentives offered by governments and NGOs to adopt land management practices to conserve wildlife and its habitats. One estimate is that one-quarter of surviving native grassland is on soil classes one to three: that is, on quite fertile soils and therefore at a high risk of being ploughed (Hammermeister et al., 2001).

\section{Ecological Simplification of the Prairies}

Within one human lifetime, the prairies have passed from wilderness to become the most altered habitat in this country and one of the most disturbed, ecologically simplified and overexploited regions in the world.

Adrian Forsythe (1983: 66)

Friesen (1984) recognises three phases in European impacts on the prairie. In the first phase, hunters and trappers had a lasting adverse impact on ecological integrity by almost eliminating the bison (Bison bison), the plains wolf (Canis lupus), the swift fox (Vulpes velox), the black-tailed prairie $\operatorname{dog}$ (Cynomys ludovicianus) and the plains grizzly bear (Ursus arctos). The second phase, from about 1880, saw the mixed-grass prairie opened up to ranching when the federal government leased large areas for cattle- and sheep-rearing to individuals and companies from Europe, eastern Canada and the USA. The third phase saw the influx of farmers between 1900 and 1930, with native grassland ecosystems disturbed by dry-farmed cereals, mainly wheat (Triticum aestivum) and irrigated crops. Commercial agriculture also introduced many non-native plant species into farm 
fields and open range, for example by the wholesale reseeding of millions of hectares of range during droughts with exotic forage grasses such as crested wheatgrass (Agropyron cristatum) and smooth brome (Bromus inermis). Although pastures seeded to crested wheatgrass increase grazing capacity and extend the grazing season in spring and autumn, they severely reduce the biodiversity of native grasses and herbs, which after 30 years can account for only 10 per cent of the vegetation. Escapes of exotic species from prairie parks and gardens have also occurred.

A further impact of settlement has been the control of natural and man-made fires, a condition which favours the spread of shrubs and trees such as aspen (Populus tremuloides) at the expense of native grasses. Bison are attracted to the regrowth after a fire, a fact noticed by aboriginals, who used fire to manage prairie. Fire was also used for driving herds in hunting. In present times, ecological integrity continues to be diminished by a long list of human impacts: habitat destruction for agriculture, forestry, urbanisation, rural acreages and cottages, oil and gas wells, predator control (legally or illegally), the introduction (deliberately or accidentally) of exotic species, the widespread use of fertilisers and pesticides, and 'improvements' through slough-drainage, reseeding and irrigation.

Two depressing estimates are that 80 per cent of the native grasslands of Saskatchewan and Alberta have been ploughed (Selby and Santry 1996), and that Saskatchewan has lost all but 6 per cent of its mixedgrass prairie (Samson et al. 1998). Furthermore, these statistics mask the fact that most of the remaining natural or semi-natural prairie occurs in isolated small patches like roadside and railway verges, banks of rivers and ditches, undrained sloughs, and quarter-sections that for accidental reasons have never been ploughed. The ecologist uses the concept of geographical range to denote the size of the area needed for a plant or animal species to exist successfully. The ranges of prairie wildlife tend to be large, and fragmented patches or small restored plantings of native plants are usually not big enough to recreate the original ecosystem. As a generalisation, for historical, economic and political reasons, conservation areas are larger, and therefore are more valuable as conservation units, in the prairies of the USA. 


\section{What is Native Prairie?}

we suspect that grasslands once ploughed can never be restored to their primeval state; we cannot resurrect the past, and only with luck and hard work will we be able to preserve the fragments of semi-natural grassland that remain.

It would be useful to know the composition of the original grassland vegetation, partly for research reasons but also to have a yardstick for restoration schemes aiming to recreate these pre-settlement ecosystems. However, the grassland has been so completely modified that it is difficult to ascertain what is 'natural' or 'representative'. Detailed ecological surveys were not started until the 1940s, after the majority of the ecozone had been brought into agricultural use and fragmented. A significant majority of the areas to survive with least change are those in soil class 4 and worse, and unsuited to cultivation due to sandiness, stoniness, salinity, steepness or aridity. They are therefore atypical of much of the native prairie. Examples of large sites to escape the plough are military camps at Suffield, $\mathrm{AB}$ and Dundurn south of Saskatoon, and the ranches in semi-arid southern Alberta and Saskatchewan. An example is the Matador Ranch north of Swift Current, SK, which served as Canada's most important experimental site in the International Biological Programme (IBP) of 1966 to 1974 (Coupland et al., 1974). It was official policy to promote the 'breaking' of native grassland for cultivation or 'pasture improvement' until relatively recently. For example, several hundred hectares of native Agropyron-Koeleria grassland in the Matador Community Pasture were broken in the 1970s.

Despite the atypical character of remaining virgin mixed-prairie grassland, the prairies have been fortunate in having the studies of Bob Coupland (1950 et seq.) and his teams. Coupland shows that three factors have always been pre-eminent in shaping the ecozone's vegetation during the ten thousand years of post-glacial times: the unpredictable and variable droughts; grazing by large herds of herbivores such as bison and pronghorn antelope (Antilocapra americana); and fire. The native prairie remaining today is continually being monitored by satellite surveys and geographical information science (GIS) databases. About 25 per cent of the prairie ecozone is in grazing lands or range lands. However this total looks set to decrease, given present predictions of world food prices in the short and medium term. Questions that require answers are: How 
much native prairie is left? What are the sizes of the sites? What is the quality of the sites? What are the threats and stresses that threaten their continued survival? Table 1 provides probably the best estimate of this.

Table 1 Vegetation cover of the prairie ecoregions in Saskatchewan

\begin{tabular}{lccccc}
\hline Ecoregion & $\begin{array}{c}\text { Area } \\
\left(000 \mathrm{~km}^{2}\right)\end{array}$ & $\begin{array}{c}\text { \% native } \\
\text { grassland }\end{array}$ & $\begin{array}{c}\text { \% crops and } \\
\text { seeded pasture }\end{array}$ & \% woods & \% water \\
Aspen parkland & 81.7 & 13 & 71 & 9 & 6 \\
$\begin{array}{l}\text { Moist mixed } \\
\quad 67.8\end{array}$ & 16 & 76 & 3 & 5 \\
$\quad$ grassland & & & & & \\
Mixed grassland & 86.4 & 31 & 62 & 2 & 5 \\
Cypress upland & 5.0 & 71 & 22 & 5 & 2 \\
\hline
\end{tabular}

Source: Hammermeister et al. 2001.

There has been much interest recently in using native species to recreate native grasslands, whether as cover for wildlife habitat, for grazing or for reclaiming disturbed sites such as eroded lands or abandoned mine lands (Redmann 1995). Plantings of native species can also be seen in urban parks, on university campuses and in urban building projects. Revegetation of areas ploughed in the past or now dominated by exotic grasses is part of the management of Grasslands National Park (Parks Canada 2002). These are all worthwhile activities, but this is strictly prairie revegetation rather than prairie restoration. Restoration aims to recreate the original virgin ecosystem at a particular site. If we do not know what that state was, it is impossible to return to it.

\section{Conservation Initiatives on the Prairies}

All Dominion Parks are game sanctuaries, but the question of game outside the parks is of vital concern.

James Harkin (1914: 5)

Conservation in the prairies is not new. One important concern of the fledgling federal Parks Branch early in the twentieth century was the threat of imminent extirpation for the pronghorn antelope (Antilocapra americana) 
on the prairies, due to loss of habitat to farming and settlement, the building of roads and railways across migration routes, and indiscriminate shooting by settlers and Indians alike. Fortunately their impending fate came to the attention of three giants of the early conservation movement in Canada: James Harkin, first Dominion Parks' Commissioner; Maxwell Graham, first Head of the Animal Division of the Parks Branch; and Ernest Thompson Seton, writer and wildlife-consultant. Their joint efforts led in 1914-15 to the setting aside and fencing-in of three antelope sanctuaries near Pakowki Lake and Medicine Hat in Alberta, and Maple Creek in Saskatchewan. These received Dominion Park status in the 1920s, and so successful was the recovery in pronghorn numbers that the sanctuaries were abolished in the 1930s and 1940s and the land returned to the provinces.

Two observations are pertinent to this successful venture. First, success was not achieved without the cooperation and enthusiastic participation of local landowners, in this case ranchers, and specifically Edgar McHugh, who deeded part of his land as an antelope sanctuary. The arrangement was for McHugh to graze cattle in the sanctuary in winter, thus helping to break up surface ice-crusts, enabling antelope to graze more easily, but not in summer when the cattle might overgraze and prevent grasses from reseeding. Secondly, it is clear that the degree of cooperation differed from one province to another. Alberta took no action towards establishing reserves, whereas when an area along the banks of the South Saskatchewan River north of Swift Current was set aside as a Dominion Forest Reserve, it was declared a game preserve by a conservationconscious Saskatchewan government at the same time (Foster 1998).

Currently, two significant pieces of federal legislation are important in setting conservation priorities in the prairies. First, since it was set up in 1977, the Committee on the Status of Endangered Wildlife in Canada (COSEWIC) has provided an early-warning system for species-at-risk, which it classifies using four categories: extirpated, endangered, threatened and vulnerable. It identifies 14 per cent of the 353 species-at-risk in Canada as occurring in the prairie ecozone (COSEWIC 2000). In other words, one-seventh of species-at-risk in Canada occur on one-twentieth of the surface of the country.

Secondly, the federal Species-at-Risk Act 2004 gives priority to three important ecological aims: first to prevent extinction or extirpation of native species; second to promote recovery plans for those species extirpated, endangered or threatened as a result of human activities; and third to manage 'species of special concern': that is, species especially vulnerable to human activities and/or natural events. Several historic species 
of the Canadian prairies have been extirpated, including the black-footed ferret (Mustela nigripes), the grizzly bear (Ursus arctos), the swift fox (Vulpes velox) and the wolf (Canis lupus). (In the case of the swift fox, a recent rewilding programme has moved it from the extirpated to endangered class.) In addition, a large number of indigenous species exist only in small numbers and/or in small areas. These include the bison (Bison bison), the elk (Cervus elaphus), the ferruginous hawk (Buteo regalis) and the mountain plover (Charadrius montanus). Table 2 lists the mammals and birds in Saskatchewan in the four categories of risk. The situation is even worse regarding invertebrates, with 75 per cent of prairie invertebrates on the list.

Table 2 Mammals and birds at risk in the prairie ecozone of Saskatchewan

\begin{tabular}{|c|c|c|}
\hline Risk category & Mammals & Birds \\
\hline Extirpated & $\begin{array}{l}\text { Black-footed ferret } \\
\text { Plains grizzly } \\
\text { Plains wolf }\end{array}$ & Greater prairie chicken \\
\hline Endangered & Swift fox & $\begin{array}{l}\text { Burrowing owl } \\
\text { Piping plover } \\
\text { Sage thrasher }\end{array}$ \\
\hline Threatened & Bison & $\begin{array}{l}\text { Baird's sparrow } \\
\text { Loggerhead shrike } \\
\text { Sprague's pipit }\end{array}$ \\
\hline Vulnerable & $\begin{array}{l}\text { Plains pocket gopher } \\
\text { Black-tailed prairie dog }\end{array}$ & $\begin{array}{l}\text { Ferruginous hawk } \\
\text { Greater sage grouse } \\
\text { Long-billed curlew }\end{array}$ \\
\hline
\end{tabular}

Conservation Agencies on the Prairies

the Great Plains is one of the most 'owned' landscapes in North America. David Gauthier and Daniel Licht (2003: 25)

Programmes to conserve wildlife habitat and biodiversity in the prairies involve a multiplicity of interested parties. There are private landowners and lessees, in addition to urban and rural municipalities, and departments of provincial and federal government. Also, as in many countries, NGOs 
are very active, and represent a diversity of interest groups. All differ in their aims and methods, but it is possible to discern three levels of conservation agencies and organisations at the international, the national and the provincial scales, as indicated in Table 3.

Table 3 Conservation organisations relevant to Canada and the prairie ecozone of Saskatchewan

Level Organisation

International International Union for the Conservation of Nature (IUCN)

NAFTA Commission for Environmental Cooperation (CEC) Ramsar Convention

National Parks Canada (PC) - Grasslands National Park (GNP)

Nature Conservancy of Canada (NCC)*

Wildlife Habitat Canada (WHC)

Science and Management of Protected Areas Association (SAMPAA)*

Provincial Provincial Parks - Saskatchewan Environment (SE)

Conservation Data Centres (CDCs)

Prairie Conservation Action Plan Partnership (PCAP)

Saskatchewan Native Plant Society (SNPS)*

Nature Saskatchewan (NS)*

*NGO

The Nature Conservancy of Canada (NCC), a high-profile NGO which buys and leases land for preservation and conservation purposes, is renowned for its willingness to work with landowners and provincial governments. Wildlife Habitat Canada (WHC) is a coordinated group with personnel from Environment Canada (EC) - Canadian Wildlife Service (CWS) and provincial wildlife agencies; it puts most of its efforts into promoting the conservation of wildfowl and wetlands. The Science and Management of Protected Areas Association (SAMPAA) is the main NGO in Canada concerned with scientific and educational aspects of the management of protected areas. Its conferences provide opportunities for scientific exchange and aim to influence the policies of governments and land-users' associations.

At the provincial level, conservation data centres (CDCs) were 
originally set up as NGOs but are now part of government departments. The host department varies from province to province; in Saskatchewan it is in the Fish and Wildlife Branch of Saskatchewan Environment, in Alberta the Natural Heritage Office. CDCs collect data on biodiversity in both map and digital form. Other active NGOs in the Saskatchewan prairies are Ducks Unlimited, the Saskatchewan Wildlife Federation and Nature Saskatchewan (formerly the Saskatchewan Natural History Society). The Native Plant Society of Saskatchewan supports prairie restoration projects and researches into the most appropriate species. NGOs also have programmes of stewardship and easements, designed to achieve voluntary conservation by landowners. Typical stewardship programmes would be voluntary legal agreements between landowners and a recognised conservation agency to ban or restrict ploughing, grazing or fertiliser use; the landowner continues to manage the land but with environmental benefits being an important, and perhaps even the principal, aim. Both land purchases and conservation easements can be both slow and expensive to set up and administer, however.

NGOs and governments occasionally come together to promote major initiatives. In Saskatchewan, the Prairie Conservation Action Plan (PCAP Partnership 2003) is an example of an exciting, coordinated inter-agency approach to prairie conservation. The committee implementing the plan brings together representatives from: government agencies (Agriculture and Agri-Food Canada, Environment Canada Canadian Wildlife Service, Fisheries and Oceans Canada, Parks Canada - Grasslands National Park, Saskatchewan Agriculture Food and Rural Revitalization, Saskatchewan Forage Council, Saskatchewan Industry and Resources, Saskatchewan Environment and SaskEnergy), land managers (Saskatchewan Sheep Development Board, Saskatchewan Stock Growers' Association, Saskatchewan Watershed Authority and Society for Range Management - Prairie Parkland Chapter), conservation organisations (Canadian Parks and Wilderness Society, Ducks Unlimited, Native Plant Society of Saskatchewan, Nature Conservancy of Canada, Nature Saskatchewan and Saskatchewan Wildlife Federation), and research and education organisations (Royal Saskatchewan Museum, Saskatchewan Burrowing Owl Interpretative Centre, Saskatchewan Research Council, University of Regina - Canadian Plains Research Center and University of Saskatchewan College of Agriculture). Chaired by the Saskatchewan Stock Growers' Association, it provides an ambitious forum for information exchange, coordinates conservation efforts, and develops education and stewardship programmes. 
How much of the native prairie grassland that survives is located in conservation areas? Table 4 gives the picture for the entire prairie ecozone. Over 31 per cent is in land managed by government agencies, of which almost 45 per cent is managed as PFRA (Prairie Farm Rehabilitation Administration) or provincial pastures. These lands are either leased to farmers and ranchers or are managed as community pastures. The statistics illustrate that there is still a long way to go in protecting NDG.

Table 4 Surviving native dominant grassland (NDG) within conservation areas (CAs) of Saskatchewan

Conservation area (CA)

Wildlife Habitat Canada land

PFRA community pasture

Provincial community pasture

National Park GNP

Provincial parks

Ramsar site

National wildlife areas

Nature Conservancy of Canada
Native dominant grassland (NDG) in the prairie ecozone

Area $\mathrm{km}^{2} \quad \%$ of CA \% of NDG

$\begin{array}{rlr}7575 & 80 & 14.7 \\ 5477 & 83 & 10.6 \\ 1849 & 80 & 3.6 \\ 748 & 82 & 1.4 \\ 243 & 29 & 0.5 \\ 122 & 21 & 0.2 \\ 110 & 57 & 0.2 \\ 78 & 44 & 0.2\end{array}$

0.6

3.6

1.4

0.5

2

Source: Hammermeister et al. 2001.

\section{The Grazing Imperative}

In protected areas where dominant native grazers no longer exist or are in insufficient numbers to maintain their traditional ecological role, lightto-moderate grazing by domestic cattle may serve an important role in maintaining ecological integrity of grassland ecosystems.

David Gauthier (1998:108)

We have seen how cattle replaced the large herds of bison, pronghorn antelope and elk which once grazed the prairie (Figure 1). While overstocking and overgrazing were common in the early years of ranching, ranchers nowadays use the land in a more sustainable way and have come to be regarded as agents of conservation rather than exploitation; 
they help to protect native grassland from the plough. With sustainable husbandry (when numbers of cattle are adjusted to compensate for periods of drought, and rotational grazing is practised) there is evidence that cattle-grazing has a beneficial role in managing prairie grassland. Among ranchers and NGOs there has been a revival of interest in reseeding disturbed pastures with native prairie grasses, as advocated by the provincial Prairie Conservation Action Plan (PCAP Partnership 2003) and by specialist groups such as the Native Plant Society of Saskatchewan. Cattle ranchers have adopted an increasingly ecological perspective on grassland management; this comes from a better understanding of the invasive character of exotic forage grasses, the value of grasses in soil-carbon sequestration, and the value of grassland for wildlife habitat.

Debate is ongoing about the agricultural value of native grasses compared to the exotic forage grasses used to reseed range and community pastures in the past. Some ecologists take an extreme position in calling for the removal of livestock (Donahue 1999) or the return to a kind of idealistic 'buffalo commons' (Popper and Popper 1999). However, the economic viability of the prairie livestock industry depends on exotic grass

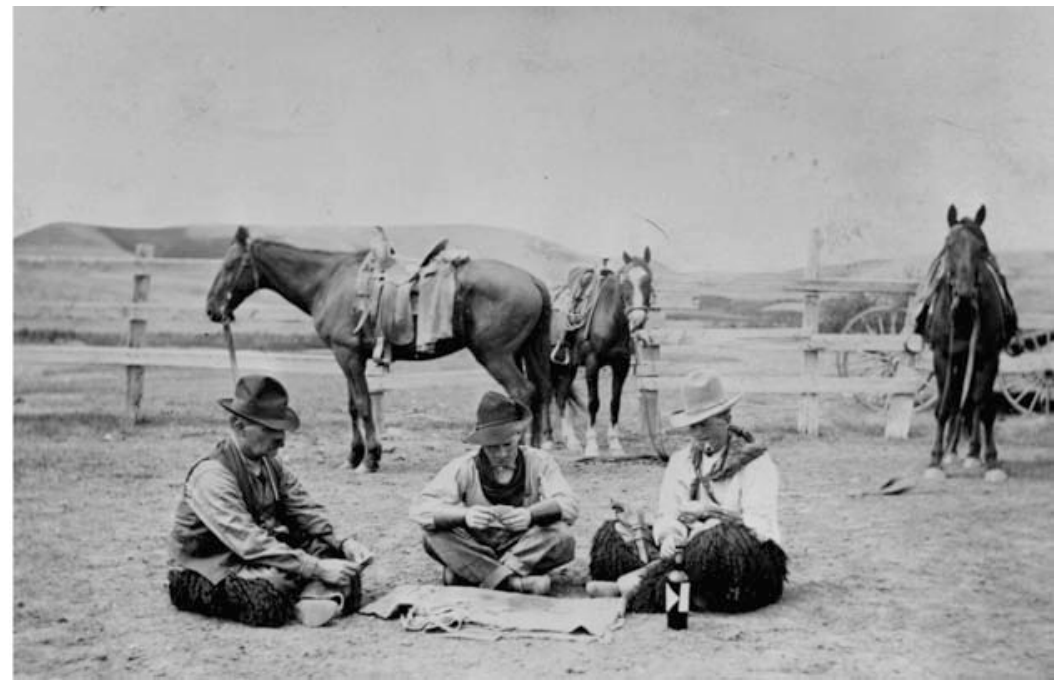

Figure 1: Ranching in Saskatchewan in 1914: lunch hour at the Turkey Track Ranch, Swift Current, with the ranch houses in the background. Note the iconic six-shooter, whisky bottle and 'chaps'. (Source: Saskatchewan Archives Board, Regina R-A2721.) 
species. If a wholesale move to native species was enforced by government policy (however unlikely this might be), economic losses would occur. Also, introduced species have been used to reduce erosion in drought years; any attempt to remove their protection of the soil surface, without a successful plan to replace them with native species, could result in environmental disaster (Jefferson et al. 2005).

Ranchers have also played their part in the recovery of native fauna. An example is that most iconic of prairie species, the burrowing owl (Athene ciricularia), whose numbers in the prairies according to some estimates have declined by 90 per cent since 1990, and whose range has declined by 50 per cent. Currently they are listed as 'endangered' in Canada and Saskatchewan, and 'threatened' in Alberta (Wellicome 2005). Some optimistic news is that numbers have recovered slightly since 2001. Troy Wellicome, owl conservation specialist with the Canadian Wildlife Service, notes that simple actions such as ranchers providing water for cattle away from creeks and wetlands can bring success. Burrowing owls nest in heavily grazed areas but hunt at night near creeks for mice. If vegetation near creeks becomes overgrazed and the land 'puddled', then there are few mice.

\section{Grasslands National Park (GNP)}

We must save endangered spaces before endangered species.

Stan Rowe (1990: 61)

GNP (Figure 2) was established in 1975 (with further agreements with the provincial government in 1981 and 1988) to protect the bestremaining area of mixed-grass prairie. The Saskatchewan Natural History Society had proposed a national park for this iconic Canadian natural region as early as the 1940 s, primarily to protect Canada's only prairie dog colony in the Frenchman River valley; but the formation of the park proved to be a controversial and protracted affair. Initially there was opposition from much, but not all, of the ranching community. During the 1980s the issue of rights to possible oil-and-gas reserves and to water caused conflict between the federal authorities and the government of Saskatchewan. It transpired that the hydrocarbon potential is low, but the provincial government stood firm on water rights. The newly created Saskatchewan Water Authority insisted on retaining water rights, pointing to the needs of regional irrigation schemes and the requirement that 50 
per cent of water reaching the border belongs to the USA under the Boundary Waters Treaty. Relationships between federal authorities and the province have improved since the turbulent 1980s, and the park authorities have made much progress working with local land-users, especially ranchers. GNP will eventually consist of two blocks totalling $900 \mathrm{~km}^{2}$; about half has been acquired so far, so that currently the park consists of a patchwork of parks lands and private farms and ranches.

Recreation opportunities in the park are wilderness-based; there is an ecotour for cars, day hiking, overnight backpacking, wildlife viewing and horseback riding. Initially local municipalities envisaged a substantial investment into recreation by Parks Canada that would boost the regional economy through tourism. However, it was never the intention of Parks Canada to invest in tourist infrastructure for GNP, and the park mostly consists of zone III (wilderness). Visits to the park only total about 67,000 per year (Grigel 2004). Numbers vary annually for economic and environmental reasons, such as the general economy, publicity given to diseases such as BSE and West Nile virus, and the severity of forest fires throughout Canada.

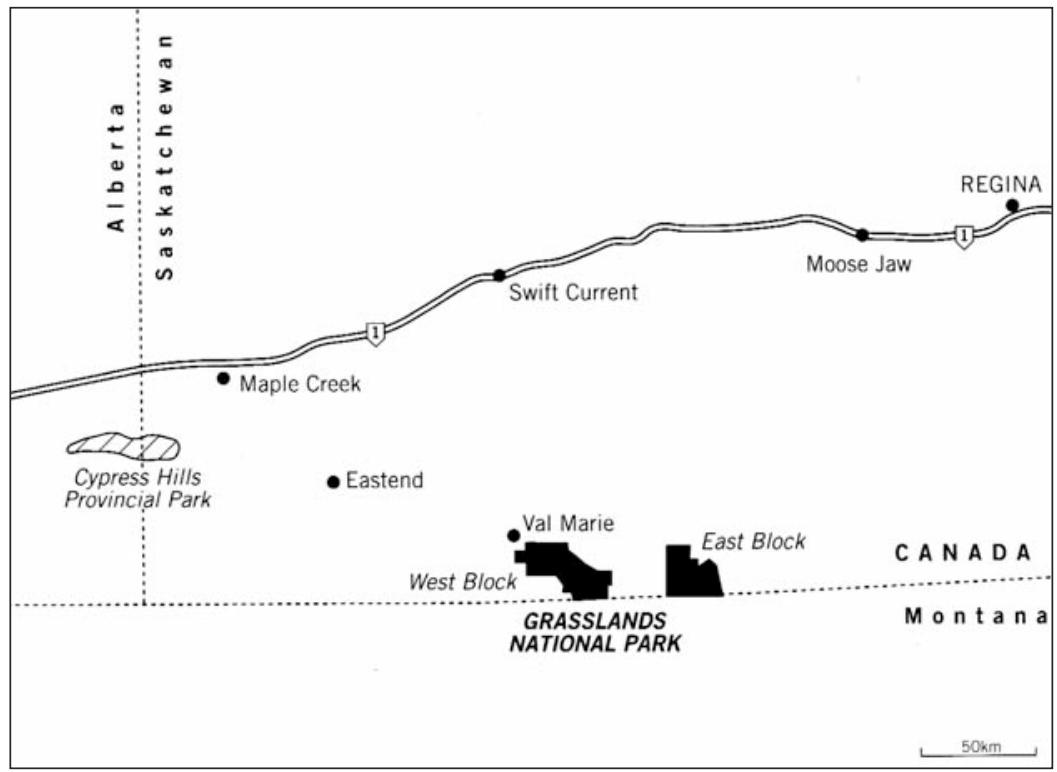

Figure 2: Location of the west and east blocks of Grasslands National Park (GNP), Saskatchewan. 
The primary aim of the park is to conserve native prairie grassland and the 300 species of wildlife that spend some part of their life cycles within it. There are projects for eliminating alien grasses like the crested wheatgrass, and also rewilding projects for bison and the swift fox (see following section). A less well-known aspect of the work of Parks Canada is to carry out and administer research into the fundamental processes that sustain ecological integrity. 'Managed grazing' is a powerful tool to investigate these, and the use of reintroduced bison in grazing experiments might seem to be the obvious strategy. However, this is not practical for logistical reasons (the need for expensive fencing, and for impossibly large experimental areas for bison to behave 'normally'), and also because of the stress caused to the animals by handling. Therefore cattle will be used as a surrogate for bison to study the effects of different grazing intensities on plants, birds, insects and small mammals. The grazing experiment is just commencing in East Block, where $39 \mathrm{~km}^{2}$ has been subdivided into 13 experimental grazing plots. The essence is to have plots large enough to allow 'patchiness' of grazing by the cattle, so that lightly-grazed areas will show tall grasses and herbs, and heavily-grazed patches will have short vegetation and bare areas. In the natural sciences, the value of large-scale field experimentation cannot be overstated, and will always be superior to experimentation in small plots, greenhouses and the laboratory. This ten-year grazing experiment is probably the largest in the world for grassland ecosystems, and will provide information of value to Parks Canada, NGOs, ranchers and managers of federal and provincial community pastures, as well as to the international community.

\section{Rewilding Initiatives on the Prairies}

The greatest needs of the moment ... are dedication to the preservation of flora, fauna and their habitats, plus dedication to instituting longterm land-use planning that recognises the importance of natural wild areas.

Stan Rowe and Robert Coupland (1984: 248)

Rewilding or ecosystem restoration means different things to different people, and on the prairies there is little consensus about the meaning of 'wildness', never mind about the wisdom of restoring it. In the UK, where the term 'reintroduction' is used by government nature agencies and NGOs, there have been various programmes, ranging from the 
reintroduction of the white-tailed sea eagle (Haliaetus albicilla) into Scotland from Norway, to breeding programmes and planned releases of the osprey (Pandion haliaetus) and the red kite (Milvus milvus) to restore the species to their historical ranges. There is also talk now of reintroducing the beaver (Castor fiber), the wolf (Canis lupus) and even the European elk (or moose) (Alces alces)! In the prairies, as elsewhere, rewilding is expensive and controversial. Supporters talk of the moral responsibility of bringing extirpated species back, and stress the excitement factor when viewing the animals.

However, where does a rewilding programme start and end? On the prairies should it include the grizzly bear, the wolf and allowing wildfires to run their course? Basically in the prairies the answers are 'no', 'no' and 'no', but there are programmes of vegetation management, fire ecology and the reintroduction of species.

There is a long list of requirements for a successful rewilding programme: good ecological knowledge of the species, secure and suitable habitat, multidisciplinary teams from government and voluntary sectors, international cooperation, cash, genetically pure stock, disease control, safe and humane handling of the animals, publicity and education of both neighbouring land-users and the general public, a monitoring programme in place, and a knowledge of, and adaptation to, any future environmental changes in the range of the reintroduced species. As this long list implies, such programmes are extremely expensive in term of cash, personnel and time. It is a process that involves much consultation with the general public, especially with neighbouring land-users, and it can easily become politicised. In the real world it raises important questions about tourism, about access and about its legal status. Should the scarce funds available for wildlife conservation be spent in this manner?

Examples of rewilding on the prairies are the bison at GNP and the Old-Man-on-his-Back conservation area of NCC, and the swift fox and the black-tailed ferret more widely. The justification for the bison programme is indisputable, as this herbivore is a keystone species and it is unthinkable that restored grassland should be without it. Its presence is not only a big step towards ecological integrity by restoring a grazing regime by a large natural herbivore, but also it has a symbolic value for publicity and a large educational impact in the minds of young people and general public alike. In GNP, 71 bison from Elk Island National Park, AB, were released into a 20-hectare holding pen in December 2005, before being released into the largest 18,000-hectare parcel of the West Block in May 2006 (Figure 3; colour image included in this online version). The 


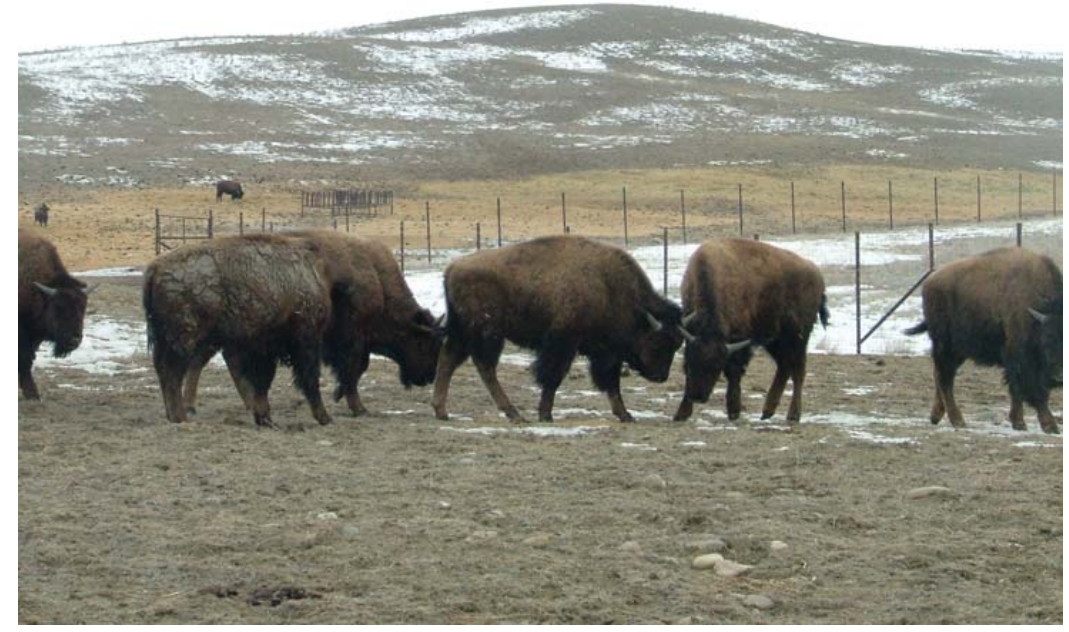

Figure 3: Reintroduced bison feeding on oats in their holding pen in GNP. (Source: Debbie Kilfoyle, Parks Canada)

reintroduction is going well, with many new calves; the large grazing management experiment described above has been launched consequent upon the bison's return to GNP after an absence of 120 years (Fargey, personal communication).

The swift fox (Figure 4; colour image included in this online version) was listed as 'extinct' in Canada in 1978, but a successful reintroduction programme began in 1983 with the importation of wild foxes from Wyoming. This small mammal disappeared from the Saskatchewan prairie about 60 years ago due to habitat loss, trapping and as an indirect casualty of a poisoning programme directed at the coyote (Canis latrans). About 1,000 animals have been released into suitable habitat in Canada and the USA from captive-breeding programmes at places like the Cochrane Ecological Institute, Cochrane, AB. There was a population of about 200 in Canada in 1995 (Wiltse 1995), with the result that in Saskatchewan the status of swift foxes was changed from 'extirpated' to 'endangered' in 1998. One estimate is that it costs $C \$ 20,000$ for each released fox. The success of the programme is encouraging, as a pair of 


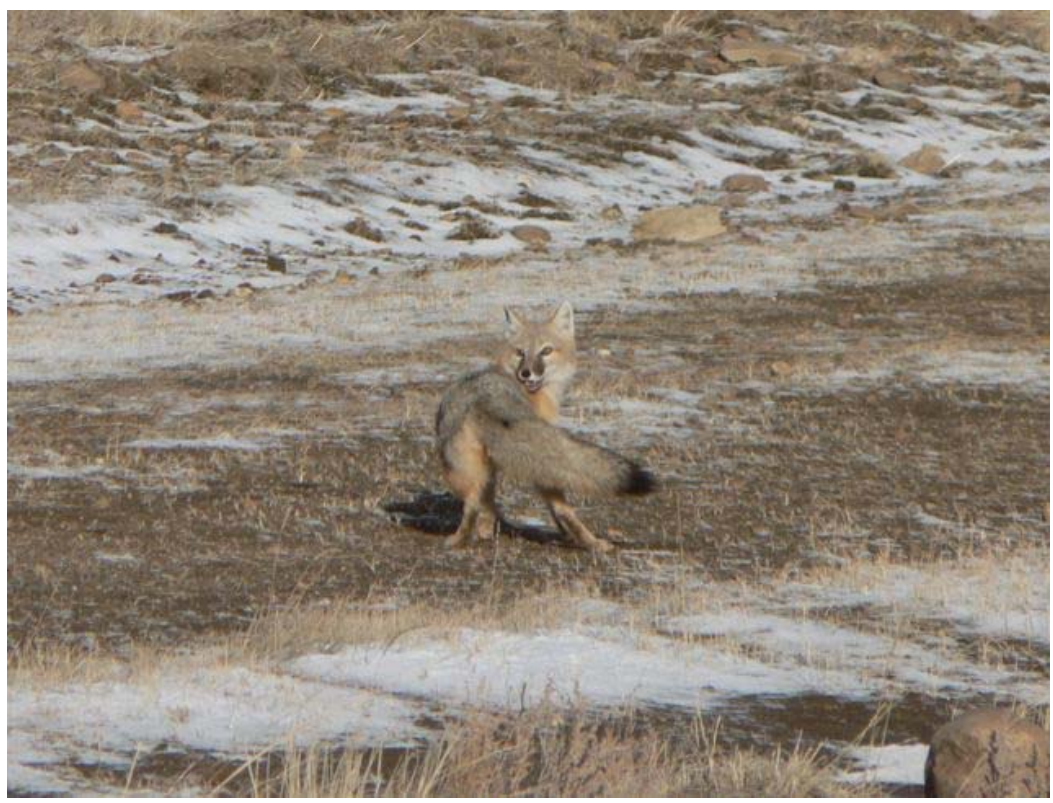

Figure 4: The swift fox is restricted to short-grass and medium-grass prairie. Once classed as extirpated in the prairies, there is now a population of over 200. With an average weight of $3 \mathrm{~kg}$, it is the size of a domestic cat. (Source: Chris Reed, Conservation Research Section, Calgary Zoo)

swift foxes needs a range of about $40 \mathrm{~km}^{2}$ of flat, intact native prairie. One calculation is that a self-sustaining population of swift foxes will require all the remaining prairie, plus corridors of native prairie to connect larger patches. Much of the success of the swift fox programme is based on firstclass ecological research and monitoring (Sovada and Carbyn 2003).

Rewilding programmes are also affected by legal questions of jurisdiction and governance, a not infrequent occurrence with natural resources management in Canada. In 2005 a dispute arose over the release of swift foxes on Blood Indian Reserve Land, west of Lethbridge, $A B$. Under the Species-at-Risk Act, the project managers need a federal permit. However, the provincial government, in the form of the Fish and Wildlife Division of Alberta Sustainable Resource Development, also wanted them to get a provincial permit to ensure disease biosecurity, humane treatment of the animals and monitoring of the recovery results. The Blood Tribe Land Management Group disputed the legal requirement 
for a provincial permit, but the province insisted on its own permit, declaring that the federal monitoring programme was inadequate (Quinlan 2005).

\section{Prairie Conservation and Environmental Change}

Effects of future environmental changes on soils, vegetation and wildlife will be dramatic and far-reaching.

Smithson et al. (2008: 722)

One of the principal supporters of research into climate change in Canada is the Climate Change Action Fund. The main thrust of its work is adaptation to inevitable change, rather than moderation of the degree of change. This may appear to be a defeatist approach, but it is probably the most realistic, and promises to achieve maximum ecological integrity in the future. The Canadian Plains Research Center (CPRC) administers several projects relevant to environmental change: 'Status of native prairie habitat, prairie ecozone, Saskatchewan' (Gauthier, Patino and McGovern 2002) and 'Generation of a GIS model to predict the impact of climate change on fragmented prairie biodiversity' (ongoing). Also at CPRC, Lorena Patino, Head of GIS Services, has prepared a CD of climatic and ecological predictions for the Prairie Ecozone for 2050. Another five-year project by CPRC is to publish predictions of climate change based on different modelling scenarios. In a project entitled 'Institutional adaptations to climate change: comparative study of dryland river basins in Canada and Chile', funded by SSHRC and administered by CPRC, an assessment is being made of the ability of prairie institutions to formulate strategies to adapt to climate change. The South Saskatchewan River Basin is one of the chosen case studies. Institutions like the Prairie Farm Rehabilitation Administration (PFRA), set up by the federal government in response to catastrophic droughts in the 1930s, already have a good reputation for dealing with the variability and unpredictability of precipitation in agriculture. However, in conservation one asks the question: if the scenario for 2050 is towards drought, what actions are needed?

Parks Canada is particularly concerned about environmental change, not least because the nationwide parks system is based on the present distribution of natural regions in the country. One important criterion in the choice of location is that every natural region should have at least one representative park within its boundaries. If, as predicted, the spatial 
extent of these regions changes, a re-evaluation of the network will be needed, certainly as regards future additions (Rizzo and Wiken 1992). In the case of GNP, where many species are already at the limits of their range, one needs to answer questions raised by computer modelling. If conditions become much drier, are the rewilding programmes taking this into account? Why reintroduce the swift fox if habitat conditions are destined to deteriorate? There is a danger that environmental scenarios for 2050 will be regarded by bureaucrats as too remote, too uncertain and too academic. However, why expend scarce resources of time, effort and money on rewilding if there are serious doubts about future habitats? Conservation organisations like Parks Canada and the Nature Conservancy of Canada will need to use future scenarios predicted by climate models in their medium- and long-term planning.

Environmental change generally produces winners and losers, and there is inevitably speculation about individual cases. Under the predicted 'warm dry' scenario, large herbivores like bison would struggle with the lower grassland production, whereas adult grasshoppers would increase with the lower rainfall, thus helping many birds including the endangered burrowing owl. With climate warming, the biodiversity of amphibians and reptiles, many of which are at the northern limits of their range, might be expected to increase by in-migration from the warmer south. However, should the Frenchman River and other wetlands become much smaller, or disappear altogether, the only survivors would be those whose physiology and behaviour are well adapted to aridity.

\section{Aboriginal Involvement in Prairie Conservation}

Given the prehistoric and historic importance of aboriginal occupancy in the prairies, it is a surprise that there is little aboriginal involvement in the conservation initiatives discussed here, despite many attempts by government agencies and NGOs at involvement and cooperation. The reasons for non-involvement are complex. One factor is that despite the wealth of aboriginal settlement in prehistoric and historic times, most present-day aboriginal communities in Saskatchewan are in the aspen parkland and boreal forest natural regions to the north.

There are also political factors at work. Aboriginal communities generally want power, to be leaders, and to be able to make decisions. 'Ownership' and 'political rights' are their main concerns. If these questions are not on the table, they are reluctant to cooperate. They resent being 
regarded as mere 'stakeholders'. It is also true that correct approaches to aboriginal communities need to be made through Elders. There are many aboriginal archaeological sites in GNP, many of which would be regarded as sacred. However, Parks Canada owns the land, and aboriginals do not wish to recognise this ownership. It is a minefield of political motivations and manoeuvrings, and one can have sympathy with both sides. The situation has been called: 'broken expectations rather than broken promises'. The perception exists among aboriginal communities that federal government agencies like Parks Canada invite advisers (including aboriginals) to meetings, listen to their views and assessments, but then make all important decisions without their input. If the federal government does not power-share, everyone else is just an adviser. Aboriginal elders wish to be treated as a body of governance and to become totally involved, but whether this is possible in the field of conservation is debatable.

\section{Conclusions: Seven Pillars of Wisdom in Prairie Conservation}

The essence of what we risk losing when the grasslands are destroyed is not a species here or a species there, but a quality of life, the largeness and wildness that made this country remarkable.

Adrian Forsyth (1983: 78)

Do the experiences of nature conservation in the grasslands of southern Saskatchewan provide any conclusions of national significance for conservation in twenty-first century Canada? Or are we dealing with a unique regional case-study: one of some interest, but probably marginal in its national significance? We can recognise seven ways in which the prairies might offer beacons for conservation:

Conservation in the prairie ecozone is based on a sound scientific knowledge of its ecology. This has involved longstanding field and laboratory studies of entire ecosystems as in the Matador IBP project, and of individual species of flora and fauna over many years. Currently the grazing experiment in Grasslands National Park continues this tradition. Also, excellent use is being made of many databases and computer models compiled by geographical information science (GIS), and of important questions about conservation areas, the ecological land classes they occupy, and the status of native prairie plants.

Conservation is as much about people as about nature. The prairies 
have been fortunate in having far-sighted conservationists active in their universities, NGOs and government agencies. The efforts of James Harkin, Maxwell Graham and Ernest Thompson Seton in the early years of the twentieth century have been continued in the late twentieth century by the research, public service and teaching of ecological giants like Bob Coupland, Howard Richards and Stan Rowe at the University of Saskatchewan, and George Ledingham at the University of Regina. The vision is currently being carried forward by many dedicated workers, including Dave Gauthier (Director of the Canadian Plains Research Center (CPRC), University of Regina), Cheryl Penny (superintendent) and Pat Fargey (species-at-risk specialist) with Parks Canada at GNP. The literary impetus for concern about wilderness has been greatly helped by writers such as Wallace Stegner (former long-time resident of Whitemud, SK) and Sharon Butala (resident of Eastend, SK).

Nature conservation relies on cooperation. It works best with conservation groups working together, and cooperating with neighbouring land-users. These might be farmers, ranchers, foresters, industrialists, miners, recreation managers or urban developers. Cooperative activities include consultations, easement and stewardship programmes, impact workshops, and educational, social and cultural events. This field presents a great challenge for the creative imaginations of conservationists, in order to produce innovative and cooperative projects like the Prairie Conservation Action Plan (PCAP).

The prairies provide an example of how tensions between conservationists and other land-users can be healed and need not be permanent. In the past there was animosity between conservationists and ranchers, with the former accusing the latter of overgrazing and using exotic grasses to reseed pastures. For their part ranchers regard themselves as 'conservers' and resent being called 'destroyers', pointing out that their open range gives native flora and fauna some chance of survival. They regard themselves as custodians of the land and its natural organisms, and resent being moved off conservation areas. Fortunately, understanding between ranchers and conservationists has improved enormously in the past two decades, largely as a result of the efforts of GNP and the NCC. For example, the tensions between Parks Canada and a small but vocal minority of ranchers and farmers consequent upon the establishment of GNP in the 1970s have now mostly disappeared.

There are many agencies and NGOs working to preserve the ecological integrity of prairie ecosystems. The comment has been made that too many bodies might be a sign of weakness, with energies and funds being 
dissipated in search of diverse goals. Different NGOs have different aims and methods, and in some respects will be competing for resources and publicity. However, on balance, the diversity of conservation bodies is a sign of strength rather than weakness. The complexity of the natural world and the multiplicity of actions required to maintain ecological integrity and biodiversity are best served by a variety of state and voluntary organisations.

It follows from the above that a diversity of criteria is needed in order to achieve conservation goals. Alteration of prairie ecosystems has been so extreme that much focus has been put on species-at-risk by both federal and NGO conservation bodies. The province, through Saskatchewan Environment (SE), puts more priority on preserving typical habitats within the province through its Representative Areas Network. Other agencies emphasise the need to protect rare and unique species and their habitats, such as the prairie dog colony in GNP, and prairie rattlesnake hibernacula. The federal government stresses biodiversity, signs up to international protocols and declares national action plans. However, how far can it commit a province like Saskatchewan, which might have other conservation priorities and might resent paying the ever-increasing costs of these federal initiatives?

Finally, we must recognise that, in Canada as in other countries, an important debate is emerging about the future direction for conservation. One school of thought regards rewilding as the most creative and proactive way forward in the twenty-first century, arguing that conservation has been on the back foot for too long, and has over-concentrated on protecting nature from outside threats. In the UK, Peter Taylor has been an insistent voice for the reintroduction of a long list of lost species like the beaver, the wolf, the European elk (moose) and the lynx (Taylor 2005). We have seen that in the prairies a compelling case can be made for reintroducing the bison as a keystone species, and the swift fox as an extirpated rarity. However, rewilding is expensive and controversial, and can easily become an idealised, romantic myth ignoring reality. Clearly it would be inappropriate to reintroduce the prairie wolf, the plains grizzly bear, and the widespread use of fire, all key features of natural prairie ecosystems. Instead, because many threats to ecological integrity still exist, it is difficult not to agree with those who argue that our priorities should continue to be the protection and conservation of what we still have, the remaining areas of natural and semi-natural grassland. These should be the main focus of our money and efforts. This opinion is shared by many in the UK; the distinguished ecologist Oliver Rackham (2007) is 
among those who argue that protection must take precedence over restoration. It is important that we get it right because, in the words of a former Minister of Canadian Heritage: 'We may live in cities but nature is in our souls' (Copps 2002: i).

\section{Acknowledgements}

Fieldwork in the prairies was made possible by financial support from the Foundation for Canadian Studies, UK, and the School of Geography, University of Leeds. I would like to thank the following staff of Parks Canada at Grasslands National Park, Val Marie, SK: Cheryl Penny, superintendent, for allowing me to sit in on a GNP Management Meeting; and Pat Fargey, species-at-risk/ecosystem management specialist, for many discussions and for inviting me on a field trip with parks staff, which allowed me to soak up knowledge under a cloudless, azure prairie sky, and to hear, but not see, a prairie rattlesnake. I also thank Susan Robertson for an instructive field trip on grassland ecology, Debbie Kilfoyle for details of the GNP bison reintroduction plan, Colin Schmidt for visitor data for GNP, and Garry Adams, archaeology specialist at Parks Canada (Western Canada Service Centre, Winnipeg, MB) for leading a field trip on the aboriginal archaeology of GNP.

Personnel at the Canadian Plains Research Center, University of Regina have been extremely helpful in discussing issues and in providing details of their many research projects. My warm thanks go to Dave Gauthier, for answering many questions; and Lorena Patino, geographical information services coordinator, for providing databases on conservation areas in Saskatchewan, and climatic and ecological scenarios of the prairies in 2050. Equally warm thanks are due to Rory O'Hagan, teacher and concerned citizen of the city of Regina, who shared with me his visions and great enthusiasm for wild places. Finally I thank David Appleyard at the Graphics Unit of the School of Geography, University of Leeds, for drafting the map.

\section{References}

Atkinson, Kenneth, 2003, 'Wilderness and the Canadian Mind', British Journal of Canadian Studies, 16:2, 228-42.

Atwood, Margaret, 1995, Strange Things: The Malevolent North in Canadian 
Literature (Oxford: Clarendon Press).

Copps, Sheila, 2002, 'Foreword', in Parks Canada, 2002, Grassland National Park Management Plan (Ottawa, ON: Queen's Printer).

Coupland, Robert T., 1950, 'Ecology of the mixed prairie in Canada', Ecological Monographs, 20, 386-405.

Coupland, Robert T., 1991, 'Mixed prairie', in Robert T. Coupland (ed.), Natural Grasslands: Introduction and Western Hemisphere (London: Elsevier), pp. 151-81.

Coupland, Robert T., J.R. Willard and Earl A. Ripley, 1974, Matador Project: Technical Report No. 69 (Saskatoon, SK: University of Saskatchewan).

COSEWIC, 2000, Canadian Species at Risk (Ottawa, ON: Environment Canada). Donahue, Debra L., 1999, The Western Range Revisited: Removing Livestock From Public Lands to Conserve Native Diversity (Norman, OK: University of Oklahoma Press).

Eidsvik, Harold K., 1989, 'The Status of Wilderness: An International Overview', Natural Resources Journal, 29, 57-82.

Environment Canada, 1999, The Importance of Nature to Canadians: Survey Highlights (Ottawa, ON: Queen's Printer).

Environment Canada, 2003, Species at Risk: A Guide to Canada's Species at Risk in the Prairies (Ottawa, ON: Queen's Printer 2003).

Fargey, Karin S., Shelly D. Larsen, Sherri J. Grant, Pat Fargey and Colin Schmidt (eds), 2000, Grasslands National Park Field Guide (Val Marie, SK: Prairie Wind and Sage - Friends of Grasslands).

Forsythe, Adrian, 1983, 'The End of Emptiness', Equinox, 11, 66-78.

Foster, Janet, 1998, Working for Wildlife: The Beginning of Preservation in Canada, second edition (Toronto, ON: University of Toronto Press).

Friesen, Gerald, 1984, The Canadian Prairies: A History (Toronto, ON: University of Toronto Press).

Gauthier, David A., 1998, 'Biophysical Impacts of Extensive, Commercial Cattle Grazing, North American Grasslands', in G.W. Pepper and David A. Gauthier (eds), Saskatchewan Prairie Biodiversity Study: Canada/Saskatchewan Green Plan Agreement (Ottawa, ON: Queen's Printer), pp. 94-121.

Gauthier, David, Alberto Lafon, Theodore Toombs, Jürgen Hoth and Ed Wiken, 2003, Grasslands: Towards a North American Conservation Strategy (Regina, SK: Canadian Plains Research Center, and Montreal, QC: Commission for Environmental Cooperation).

Gauthier, David and Daniel Licht, 2003, 'The Socio-economic Context for Swift Fox Conservation in the Prairies of Canada', in Marsha A. Sovada and Ludvig Carbyn (eds), Ecology and Conservation of Swift Foxes in a Changing World (Regina, SK: Canadian Plains Research Center), pp. 19-28.

Gauthier, David, Lorena Patino and Katherine McGovern, 2002, Status of Native Prairie Habitat, Prairie Ecozone, Saskatchewan (Regina, SK: CPRC). 
Grigel, Frank, 2004, 2003 Survey of Visitors to Grasslands National Park of Canada (Winnipeg, MB: Western Canada Service Centre, Parks Canada).

Hammermeister, Andrew, David Gauthier and Katherine McGovern, 2001, Saskatchewan's Native Prairie: Statistics of a Vanishing Ecosystem and Dwindling Resource (Saskatoon, SK: Native Plant Society of Saskatchewan).

Harkin, James, 1914, 'Memorandum Regarding Dominium Parks - Their Values and Ideals', NWT Game Administration Records, MG 30 C 63, Vol. 1 .

Jefferson, Paul G., Alan D. Iwaasa, Michael .P. Schellenberg and J.Grant McLeod, 2005, 'Evaluation of Native Plant Species for Seeding and Grazing by Livestock on the Semiarid Prairie of Western Canada', in Todd A. Radenbaugh and Glenn C. Sutter (eds), Managing Changing Prairie Landscapes (Regina, SK: Canadian Plains Research Center), pp. 79-100.

Parks Canada, 2002, Grassland National Park Management Plan (Ottawa, ON: Queen's Printer).

Parks Canada, 2005, Plains Bison (Bison bison) Reintroduction Plan for Grasslands National Park (Val Marie, SK: Parks Canada).

PCAP Partnership, 2003, Saskatchewan Prairie Conservation Action Plan 20032008 (Regina, SK: Canadian Plains Research Center).

Popper, Frank J. and Deborah E. Popper, 1999, 'The Buffalo Commons: Metaphor as Method', Geographical Review, 89, 491-510.

Quinlan, Richard, 2005, 'Swift Foxes Caught Up in Red Tape', Lethbridge Herald (24 September).

Rackham, Oliver, 2007, Woodlands (London: Collins).

Radenbaugh, Todd A. and Glenn C. Sutter (eds), 2005, Managing Changing Prairie Landscapes (Regina, SK: Canadian Plains Research Center).

Redmann, Robert E., 1995, 'Restoration of grassland ecosystems - agronomy or ecology?' in W.D. Willms and J.F. Dormaar (eds), Proceedings of the Fourth Prairie Conservation and Endangered Species Workshop (Edmonton, AB: Provincial Museum of Alberta), pp. 88-94.

Rizzo, B. and Ed Wiken, 1992, 'Assessing the sensitivity of Canada's ecosystems to climate change', Climate Change, 21, 43-50.

Rowe, J. Stan, 1976, 'Vegetation of the prairies', Canadian Plains Studies, 6, special issue: 'Man and Nature on the Prairies', 46-58.

Rowe, J. Stan, 1990, Home Place: Essays on Ecology (Edmonton, AB: NeWest). Rowe, J. Stan (1992) 'Review of Sylvan T. Runkel and Dean M. Boosa, Wildflowers of the Tallgrass Prairie, 1989, and R.C. Cushman and S.R. Jones, The Shortgrass Prairie, 1988', in Ecology, 70, 993-4.

Rowe, J. Stan and Robert T. Coupland, 1984, 'Vegetation of the Canadian Plains', in G.J. Mitchell (ed.), 'Man: User and Modifier of Canadian Plains' Resources', Prairie Forum, 9:2, 231-48.

Samson, F.B., F.L. Knopf and W.R. Ostlie, 1998, 'Grasslands', in M.J. Mac, P.A. Opler, C.E. Puckett and P.D. Doran (eds), Status and Trends of the Nation's 
Biological Resources, Vol. 2 (Washington, DC: USDA and USGS).

Savage, Candace, 2004, Prairie: A Natural History (Vancouver, BC: Greystone Books).

Scott, D. and R. Suffling (eds), 2000, Climate Change and Canada's National Park System (Ottawa, ON: Environment Canada).

Selby, C.J. and M.J. Santry, 1996, A National Ecological Framework for Canada: Data Model, Database, and Programs (Ottawa, ON: Agriculture and AgriFood Canada and Environment Canada).

Smithson, Peter, Kenneth Addison and Kenneth Atkinson, 2008, Fundamentals of the Physical Environment, fourth edition (London: Routledge).

SNH (Scottish Natural Heritage), 2002, Wildness in Scotland's Countryside (Edinburgh: $\mathrm{SNH}$ ).

Sovada, Marsha A. and Ludwig Carbyn (eds), 2003, Ecology and Conservation of Swift Foxes in a Changing World (Regina, SK: Canadian Plains Research Center).

Spry, Irene, 1976, 'The Great Transformation: The Disappearance of the Commons in Western Canada', Canadian Plains Studies, 6, special issue: 'Man and Nature on the Prairies', 21-45.

Taylor, Peter, 2005, Beyond Conservation: A Wildland Strategy (London: Earthscan). Wellicome, Troy, 2005, 'Team Gives a Hoot about Burrowing Owl', Lethbridge Herald (October 6).

Wiltse, Earl, 1995, 'Crow's Demise Raises Hope for Added Animal Habitat', Saskatoon Star-Phoenix (August 23). 